\title{
Exploring the Fit between Doctoral Students' and Supervisors' Perceptions of Resources and Challenges vis-à-vis the Doctoral Journey
}

\author{
Kirsi Pyhältö, Jenna Vekkaila, and Jenni Keskinen \\ University of Helsinki, Helsinki, Finland
}

\author{
kirsi.pyhalto@helsinki.fi, jenna.vekkaila@helsinki.fi, \\ jenni.keskinen@helsinki.fi
}

\begin{abstract}
This study explores the fit between doctoral students and their working environment by analyzing students' and supervisors' perceptions of resources and challenges involved in the doctoral process. The data were collected using online surveys. Altogether 1184 doctoral students and 431 supervisors completed the survey. The results suggest that the fit between the doctoral students' and supervisors' perceptions of resources and challenges is linked to the doctoral students' satisfaction with their studies and the supervisory relationship. In faculties where the students' and the supervisors' perceptions of resources and challenges were similar, the students reported being more satisfied with their overall study process and supervisory support. The findings indicate that the fit between students and their working environment is related to how the students' experience their doctoral process.
\end{abstract}

Keywords: postgraduate education, doctoral students, supervisor, engagement, Job-DemandsResources Model, person-environment fit.

\section{Introduction}

Supervisory relationships are central determinants that contribute to the success of the doctoral journey (Ives \& Rowley, 2005; Sambrook, Stewart, \& Roberts, 2008; Styles \& Radloff, 2001; Zhao, Golde, \& McCormick, 2007). Brailsford (2010), for instance, showed that third parties, including senior academics (i.e., supervisors), played a central role in students' decision to launch their doctorates. Moreover, Ives and Rowley (2005) found that a constructive supervisory relationship was associated with students' progress and satisfaction with their doctoral studies and, hence, with their involvement in their thesis projects. Quality supervision has also been reported to lead to a more positive postdoctoral experience (Scaffidi \& Bergnaman, 2011). Accordingly, a need to have a supervisor who fits well with student preferences has been emphasized in the literature on doctoral education (Eggleston

Material published as part of this publication, either on-line or in print, is copyrighted by the Informing Science Institute. Permission to make digital or paper copy of part or all of these works for personal or classroom use is granted without fee provided that the copies are not made or distributed for profit or commercial advantage AND that copies 1) bear this notice in full and 2) give the full citation on the first page. It is permissible to abstract these works so long as credit is given. To copy in all other cases or to republish or to post on a server or to redistribute to lists requires specific permission and payment of a fee. Contact Publisher@,InformingScience.org to request redistribution permission.
$\&$ Delamont, 1983). Supervision does not, however, exist in a vacuum between the student and the supervisor but is rather rooted within the particular context of a scholarly community (Becher, 1989; Dysthe, Samara, \& Westrheim, 2006). This means that the supervisory relationship is an arena for mediating disciplinary traditions, practices, cultures, and norms. Further, supervision 
itself is often a collective enterprise, including co-supervision and the activities of a research or seminar group (Park, 2007). Hence, doctoral supervision is highly embedded in the working environment provided by the scholarly community (Barnes \& Austin, 2009; Franke \& Arvidsson, 2011; Halse \& Malfroy, 2010; Pearson \& Brew, 2002) and is, therefore, affected by various resources and demands of the environment. The way in which demands are met and resources are used in order to overcome the challenges within the doctoral journey is highly dependent on what supervisors and doctoral students themselves identify as core challenges or resources. This is likely to further contribute to student engagement in their doctoral studies. However, little is known about how doctoral students and supervisors perceive their main resources and challenges with respect to the doctoral journey, and how the perceived fit between the students' and supervisors' perceptions contributes to students' satisfaction with their doctoral studies. This study focuses on exploring the fit between doctoral students' and supervisors' perceptions of the doctoral journey's resources and challenges. The present paper provides a literature review that focuses on doctoral students' engagement and fit between the doctoral student and their working environment. Second, the findings of supervisor and doctoral student surveys are introduced. Lastly, a discussion regarding the results is provided and implications for practice and research are presented.

\section{Engagement in Doctoral Research}

Doctoral student engagement, i.e., active involvement (Appleton, Christenson, Kim, \& Reschly, 2006; Reeve, Jang, Carrell, Jeon, \& Barch, 2004), in a doctoral project has been suggested to play a key role in the successful completion of doctoral studies (Gardner, 2007). Engaged doctoral students have been found to experience high levels of energy, to find their research work meaningful (Virtanen \& Pyhältö, in press), and to remain more persistent when they encounter problems during their doctoral journeys than students who suffer from disengagement in their doctoral studies (Tuomainen, Pyhältö, \& Lonka, 2012). Nutov and Hazzan (2011) have suggested that the doctoral process is an intensive, emotionally loaded, depleting, and inspiring process, during which the doctoral students experience a wide range of situations and emotions that may promote or decrease their engagement in their doctoral studies. The quality and quantity of student-faculty interaction, especially the supervisory relationship, has been shown to be one of the central regulators of doctoral student engagement (Knowles, 1999; Mainhard, van der Rijst, van Tartwijk, \& Wubbels, 2009; Seagram, Gould, \& Pyke, 1998). Supervision has, for example, been shown to contribute to degree completion, doctoral student well-being and satisfaction, as well as meaningful learning (Case, 2008; Haworth \& Bair, 2000; Meyer, Shanahan, \& Laugksch, 2005) Moreover, Hoskins and Goldberg (2005) reported that positive relationships with faculty and peers and as well as between students' goals and aspirations with the doctoral program, contributed to student resilience. There is also evidence that doctoral students' active involvement in the scholarly community contributes to how students experience their doctoral process (Gardner, 2008, 2010; Hopwood, 2010; Pyhältö, Stubb, \& Lonka, 2009), competences developed during their studies, time-to-candidacy, and their employment after earning their doctoral degrees (Lovitts, 2005; Martinsuo \& Turkulainen, 2011; Sainio, 2010; Wulff \& Nerad, 2006). However, empirical evidence about the factors and dynamics that contribute to doctoral student's engagement is still scarce.

\section{Dynamics between the Doctoral Student and His or Her Working Environment}

Research on the doctoral experience has shown that various environmental as well as individual factors contribute to doctoral students' engagement in their doctoral research. For instance, social support and constructive feedback as well as a good supervisory relationship have been identified as predictors of doctoral students' satisfaction, studying persistence, and wellbeing (Gardner, 
2007; Golde, 2005; Ives \& Rowley, 2005; Pyhältö et al., 2009; Stubb, Pyhältö, \& Lonka, 2011). The findings suggest that doctoral student engagement is regulated by the complex dynamic between the student and his or her working environment rather than a single personal or environmental attribute (Leech, 2012).

Building on Holland's (1985) seminal work on the Job-Fit Model, the interplay between doctoral students and their working environment that contributes to student engagement can be explored in terms of person-environment fit. Fit refers to the congruence between individuals and their environments (Edwards, 2007; Edwards, Cable, Williamson, Schurer Lambert, \& Shipp, 2006; Kristof, 1996). Previous studies on the doctoral experience imply that perceived fit or misfit between doctoral students and their working environments influences the students' doctoral experience and completion of the process (Golde, 2005). Golde (2005), for instance, found that a misfit between doctoral students' goals/expectations and the norms and practices of their scholarly community affected their persistence. A perceived misfit between doctoral students and their working environment in terms of the wrong department, problems with supervisors, and uncertain career prospects have also been shown to contribute to student attrition (Golde, 1998). In their study on departmental characteristics and student attrition Ehrenberg, Jakubson, Groen, So, and Price (2007) showed that as students are enrolled longer in their doctoral programs and as advising improves, they have a greater ability to persist and graduate. Moreover, a link has been shown between the quantity of faculty student interaction and students' involvement in research projects (Weidman \& Stein, 2003), productivity during doctoral studies (Nettles \& Millet, 2006; Yerkes, van de Schoot, \& Sonneveld, 2012), and higher rates of degree completion (M. M. Cook \& Swanson, 1978). Perceived fit has also been suggested to contribute to the ways in which doctoral students interact with their communities and how they perceive themselves (Sweitzer, 2009). Pyhältö et al. (2009), for example, found that both the definitions of "scholarly community" given by the students as well as their experiences of membership in this very community varied considerably: about one third of the doctoral students felt isolated from their academic community or experienced their relationship to the community as somewhat problematic. These findings indicate that various factors have an effect on perceived fit and hence doctoral student engagement.

One way to break down the complexity of factors contributing to the doctoral student engagement is to explore the fit within the framework of the Job Demands-Resources Model, which proposes that both demands and resources exist in the working environment (Demerouti, Bakker, Nachreiner, \& Schaufeli, 2001). 'Demands' refer to physical, psychological, social, or organizational working conditions and challenges therein requiring sustained effort, whereas 'resources' refers to those aspects of the work that reduce demands and challenges and which may also contribute to personal learning (Bakker \& Demerouti, 2007; Demerouti et al., 2001; Pyhältö, Pietarinen, \& Salmela-Aro, 2011). Recently, building on Bozeman's, Dietz's and Gaughan's (2001), Lovitts's (2005), and Levine's (2007) work, Leech (2012) has proposed a model that aims to consider the complexity of educating skilled and knowledgeable researchers by including multiple areas of importance, such as individual resources, program characteristics, faculty members, and location as well as a culture of discipline and graduate education, into the model. The model implies that demands and resources provided by the doctoral students' working environment could originate from various levels of the doctoral education system.

There are some indicators that doctoral students and supervisors do not necessarily have similar perceptions about the factors that contribute to doctoral studies. Doctoral students have been found to emphasize social support, interaction with researchers, and adequate funding as key resources in doctoral studies (Gardner, 2007; Protivnak \& Foss, 2009). In turn, a lack of supervision, destructive friction within the scholarly community, and problems in developing one's expertise as a scholar have been identified as core problems by the students (Pyhältö, Toom, Stubb, $\&$ Lonka, 2012). On the other hand, supervisors have been found to emphasize resources, particu- 
larly funding, as well as student characteristics such as motivation, internal locus of control, and self-direction as central ingredients of completing a doctoral degree (Gardner, 2009). Moreover, in a small-scale study on supervisors' and students' conceptions concerning supervision, Murphy (2004) showed a discrepancy between these perceptions. While the supervisors' conceptions were characterized by person-focused guidance, the students perceived supervision more often as controlling and task-focused. The findings indicate that supervisors and doctoral students may perceive different factors as constituting the main demands and resources in the doctoral journey. Supervisors, for instance, may emphasize student characteristics as core determinants of successful studying whereas students emphasize the scholarly community (Lovitts, 2001). We propose that the fit between doctoral students and their working environment may contribute to student satisfaction with their supervision and studies. Moreover, previous research on the doctoral experience suggests that the availability of resources and overcoming challenges is likely to be a central determinant for student engagement and the earning of a PhD (Appel \& Dahlgren, 2003;

Protivnak \& Foss, 2009; Pyhältö, Nummenmaa, Soini, Stubb, \& Lonka, 2012). Accordingly, in this study the doctoral student-working environment fit was explored by analyzing whether the students' and supervisors' perceptions of the resources and challenges vis-à-vis the doctoral process were similar or not. The focus is on measuring the collective fit in aggregates between the faculties and students of a particular school.

\section{Aims}

This study focused on exploring students' and supervisors' perceptions of challenges and resources in the doctoral journey. The aim was to answer the following questions:

(1) What resources and challenges did the doctoral students and supervisors identify in terms of the doctoral journey?

(2) Were there differences between the students' and supervisors' perceptions of the primary challenges and resources?

(3) Were the challenges and resources the students reported related to their satisfaction with the overall study process, supervision, and consideration of withdrawing from their doctoral studies?

(4) Did the faculties differ from each other in terms of fit between the students' and supervisors' perceptions of the primary challenges and resources?

(5) Was the fit between perceived challenges and resources related to the students' satisfaction with their overall study process and supervision?

\section{Method}

\section{Finnish Doctoral Education}

Finnish doctoral studies are highly embedded in conducting the thesis research. There is, for instance, no extensive separate course work before launching into doctoral research. Instead, seminars and course work are complimentary and designed to support the thesis project. In fact, course work (from 40 to 60 European Credit Transfer and Accumulation System (ECTS) credits depending on the discipline) included in doctoral studies is usually individually constructed and based on personal study plans that typically include international conferences as well as methodological studies. Besides course work, in Finland a doctoral degree involves a dissertation, semi- 
nars, and a public defense of the dissertation. Students must apply for acceptance to a doctoral education. After being accepted, the license to study has, until very recently, been valid for life. The average time for completing the degree is about six to seven years. Doctoral education is publicly funded and free for students, but they must pay for their living expenses. The most usual funding forms for doctoral students are personal grants, project funding, or wages from work outside the university (Pyhältö, Stubb, \& Tuomainen, 2011).

In Finland, a doctoral dissertation can be completed either in the form of a monograph or as a series of articles including a summary (Finland's Council of State, 2004). The latter consists of three to five internationally refereed journal articles co-authored with supervisors and other senior researchers, as well as a summary that includes an introduction and a discussion bringing together the separate articles. In most cases the doctoral students' mother tongue is Finnish or Swedish, but the articles and summary are written in English. The student has at least one advisor (a full professor in the relevant field) and one supervisor, who may also be the same person. Sometimes students may also have a supervisory board with members from outside the university. Doctoral students who pursue monographs often engage in seminars, and supervision is based on supervisor-student dyads rather than intensive work in research groups. Doctoral supervision is, however, usually based on an apprenticeship, in both the research groups and supervisor-student dyads. Doctoral education in Finland is described in general by the Dill et al. (2006) and Pyhältö, Nummenmaa, Soini, Stubb, and Lonka (2012).

\section{Participants}

We collected data from a large number of doctoral students and supervisors from a large research-intensive Finnish university. Different disciplines were represented in our data. The study included survey data collected from all faculties at the University of Helsinki including Agriculture and Forestry, the Arts, Behavioural Sciences, Biological and Environmental sciences, Law, Medicine, Pharmacy, Science, Social Sciences, Theology, and Veterinary Medicine. Altogether 1184 doctoral students (women: 770, 66\%; men: 383, 34\%; mode: $30-34$ years) and 431 supervisors (women: 166, 40\%; men: 252, 60\%; mode: 50-54 years) comprising all eleven faculties completed the survey. The majority of doctoral students $(65 \%)$ reported that they were working full-time on their thesis and $35 \%$ part-time. The majority of supervisors $(62 \%)$ were working as professors or research directors. The representativeness of the sample in terms of different disciplines can be considered as one of the strengths of the study. However, the response rate was rather low: the response rate among supervisors was $29 \%$ and among doctoral students $28 \%$. While the response rates remained low, the age distribution and distribution of men and women closely represented the gender distribution of the supervisors as well as the whole population of doctoral students at the various faculties (Pyhältö, Stubb \& Tuomainen., 2011; see also University of Helsinki Annual report 2010). Hence, the sample represented the whole population sufficiently in terms of gender and age distribution.

Previous studies (C. Cook, Heath, \& Thompson, 2000; Krosnick, 1999) have shown that sample representativeness is a much more important criterion for evaluating the validity of a study than response rate. Our moderate response rate among the students is likely due to the Finnish doctoral education system itself: it allows students to be enrolled for life even though in practice students may have abandoned their doctoral studies entirely. Recently a follow up system for tracking passive doctoral students has been launched. Full-time students were over represented in our sample, which indicates that those who were actively pursuing their studies were more likely to have completed the survey. 


\section{Data Collection and Instrument}

The data were collected by e-mail through online surveys in 2011 . The supervisor and the doctoral student surveys consisted of Likert-type statements and open-ended questions focusing on three themes: (1) thesis process (2) supervision, and (3) doctoral studies, as well as background questions. Approximately 20 minutes were needed to complete the survey.

Supervisors' and doctoral students' perceptions of the main resources and challenges with respect to the doctoral process were explored with open-ended questions. Moreover, students' overall satisfaction with their doctoral education and, in particular, their supervisory support was explored. Overall satisfaction with doctoral education was measured with one item "Please assess the level of your satisfaction with your doctoral education." Satisfaction with supervisory support was measured with six Likert-scale items (Pyhältö et al., 2009) that together formed a scale based on a principal component analysis (Method: Varimax). Cronbach's Alpha indicated that the scale had a good internal consistency (Table 1).

\begin{tabular}{|c|c|c|c|}
\hline \multicolumn{4}{|c|}{$\begin{array}{l}\text { Table 1: Items included on the satisfaction with supervisory support scale, } \\
\text { Cronbach's Alpha }(\alpha) \text {, mean, and standard deviation }(1=\text { fully disagree, } 5=\text { fully agree })\end{array}$} \\
\hline THE SCALE & ITEMS INCLUDED & $\alpha$ & MEAN (SD) \\
\hline $\begin{array}{l}\text { Satisfaction with } \\
\text { supervisory support }\end{array}$ & $\begin{array}{l}\text { "I receive encouragement and personal atten- } \\
\text { tion from my supervisors" } \\
\text { "I feel that my supervisors are interested in my } \\
\text { opinions" } \\
\text { "I feel appreciated by my supervisors" } \\
\text { "I often receive constructive criticism of my } \\
\text { skills and expertise" } \\
\text { "I can openly discuss any problems related to } \\
\text { my doctoral education with my supervisors" } \\
\text { "I feel that I am treated with respect" }\end{array}$ & .90 & $3.5(1)$ \\
\hline
\end{tabular}

\section{Analysis}

The answers to the open-ended questions were content analyzed using an abductive strategy. The strategy aims at the best possible understanding of the phenomenon by maintaining a continuous connection between the data and the theory (Levin-Rozalis, 2004; Morgan, 2007). This strategy was compatible with the idea of the hermeneutic circle, which involves continuous interaction between the data and developing a theoretical understanding of the phenomenon by changing aspects of the exploration (Coffey \& Atkinson, 1996). Hence, the analyzers moved back and forth between empirical observations and chosen theories when coding and categorizing the data. They also assessed the observations and theories in relation to each other in order to develop and gain the best possible understanding of the resources and challenges in doctoral process described by the students and supervisors. The analytical procedure is shown in Figure 1. In the first phase of the content analysis the doctoral students' and supervisors' answers were separately coded into two basic categories: 1) resources, meaning the most important factors that the doctoral students and the supervisors perceived as assisting and facilitating doctoral studies and the dissertation process, and 2) challenges, meaning the most important factors that the doctoral students and supervisors perceived as hindering doctoral studies and the dissertation process. 


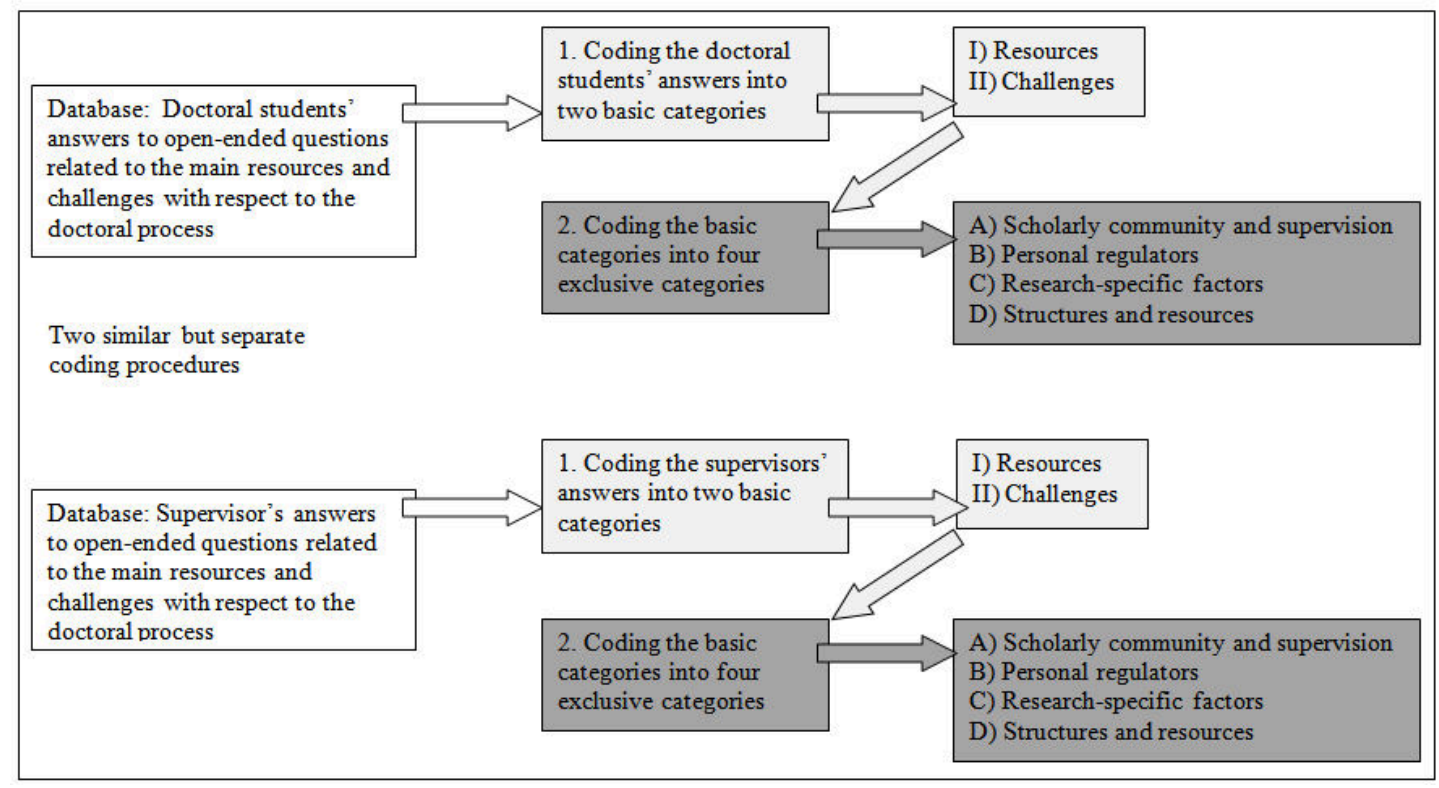

Figure 1: A visualization of the content analysis process.

After this, the two sets of basic categories (supervisors' resources/challenges; doctoral students' resources/challenges) were separately analyzed using grounded strategy to construct corresponding categories for further comparison of supervisors' and doctoral students' perceptions. The four exclusive categories were:

A) Scholarly community and supervision, including descriptions of the supervisory relationship, supervision practices, and students' participation in the scholarly community;

B) Personal regulators, containing descriptions of students' perceived motivation, selfregulation, and competence;

C) Research-specific factors, meaning descriptions of research projects, research questions as well as domain-specific know-how; and

D) Structures and resources, consisting of descriptions related to funding, time resources, and organizing the doctoral training.

The percentages presented in the results section refer to all the challenges reported by students or all resources reported by students and to all challenges or resources reported by supervisors.

In order to investigate a fit, corresponding categories needed to be created. However, in order to describe variations in students' and supervisors' perceptions about the primary challenges and resources, in the results different factors emphasized by the supervisors and students within the categories are reported.

Following this, faculties were assigned to one of three categories according to the degree of fit between doctoral students' and supervisors' perceptions of the resources and challenges in the doctoral process:

a) Fit, meaning faculties where doctoral students and supervisors had congruent perceptions of resources and challenges,

b) Partial fit, meaning faculties where congruence between students' and supervisors' perceptions existed either with respect to the resources or the challenges, and

c) Misfit, meaning faculties where students and supervisors perceived both the resources and the challenges differently. 
The categories were supported by cross-tabulations and $\chi^{2}$-tests. The categorization at the faculty level was chosen because the faculties correspond well with the disciplines at the University of Helsinki. Finally, students in the fit, partial fit and misfit categories were compared with each other in terms of overall satisfaction with their doctoral education and satisfaction with supervisory support using ANOVA. The relation of students' perceptions of promoting and hindering factors related to intentions to interrupt studies and satisfaction with supervision were analyzed with cross-tabulation and $\chi^{2}$-tests. The relation between students' perceptions of promoting and hindering factors and satisfaction with doctoral training in general was measured using ANOVA. The results were then cross-validated by analyzing the categories quantitatively after the two-phase qualitative content analysis. This provided an opportunity for triangulation, which has been used to improve the validity and reliability of the findings (Patton, 1990).

Categories derived from the content analysis were validated by the research group at the end of each analysis phase (Miles \& Huberman, 1994). In the few cases of disagreement, a consensus of final categorization was reached through discussion amongst the researchers. Faculties were also set as comparative cases to further promote the validity of the findings (Yin, 1994). The face validity (Bryman, 2004; Creswell, 2003) of the findings was tested and verified during Faculty visits in which the researchers and faculty members together reflected on the results.

\section{Results}

\section{Resources and Challenges vis-à-vis the Doctoral Process}

What resources and challenges did the doctoral students and supervisors identify in terms of the doctoral journey, and were there differences between the students' and supervisors' perceptions of the primary challenges and resources? The results indicated that in general the doctoral students and the supervisors identified rather similar kinds of resources and challenges. The resources varied from integrating into a scholarly community to being interested in research, whereas the challenges varied from a lack of funding to problems in defining the research questions. However, also differences between the supervisors' and doctoral students' perceptions about the primary resources and challenges were detected. Moreover, the supervisors and doctoral students sometimes emphasized slightly different aspects of certain resources or challenges.

The students highlighted supervision and the scholarly community (43\%), such as a constructive supervisory relationship and working in a research group, as a central resource in the doctoral process (Figure 2). Over a fifth (23\%) of the supervisors emphasized this. In the students' descriptions a constructive supervisory relationship typically included encouragement, support, engagement, and feedback from the supervisor as well as the supervisor's expertise and enthusiasm. In addition to these, the supervisors pointed out regularity of supervision as being important. Participation and interaction with other researchers and peers, as well as a supportive atmosphere in one's own research community and in the larger international scholarly community, were underlined as significant resources by both the students and the supervisors. However, within this category the doctoral students more often emphasized supervision while the supervisors emphasized both the role of the scholarly community and supervision as a central resource.

My supervisors and the group within which I conduct my research have been of the utmost importance, since they inspire me and expect me to produce high-tier research and scientific achievement. (Doctoral student)

Peer support and excellent co-workers and other doctoral students in our research centre. Because writing the dissertation is a full-time job, the people with whom I share my weekdays are the most important reasons for me to get up in the morning and come to the office. (Doctoral student) 
Working as part of a research group expands learning opportunities significantly. (Supervisor)

The supervisor's supportive contribution including regular supervisory meetings and feedback, and advice related to working schedules as well as stages and methods of academic work. (Supervisor)

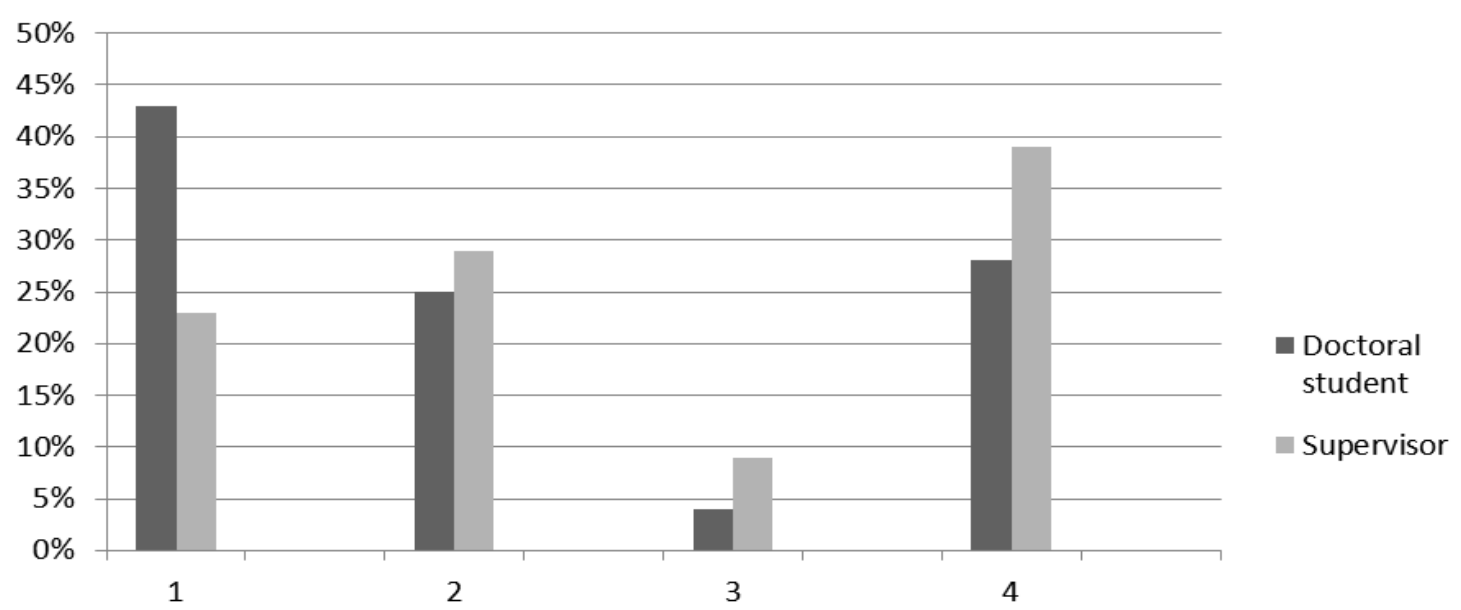

Figure 2: Resources reported by doctoral students and supervisors (1=Scholarly community and supervision, $2=$ Personal regulators, $3=$ Research-specific factors, $4=$ Structures and settings).

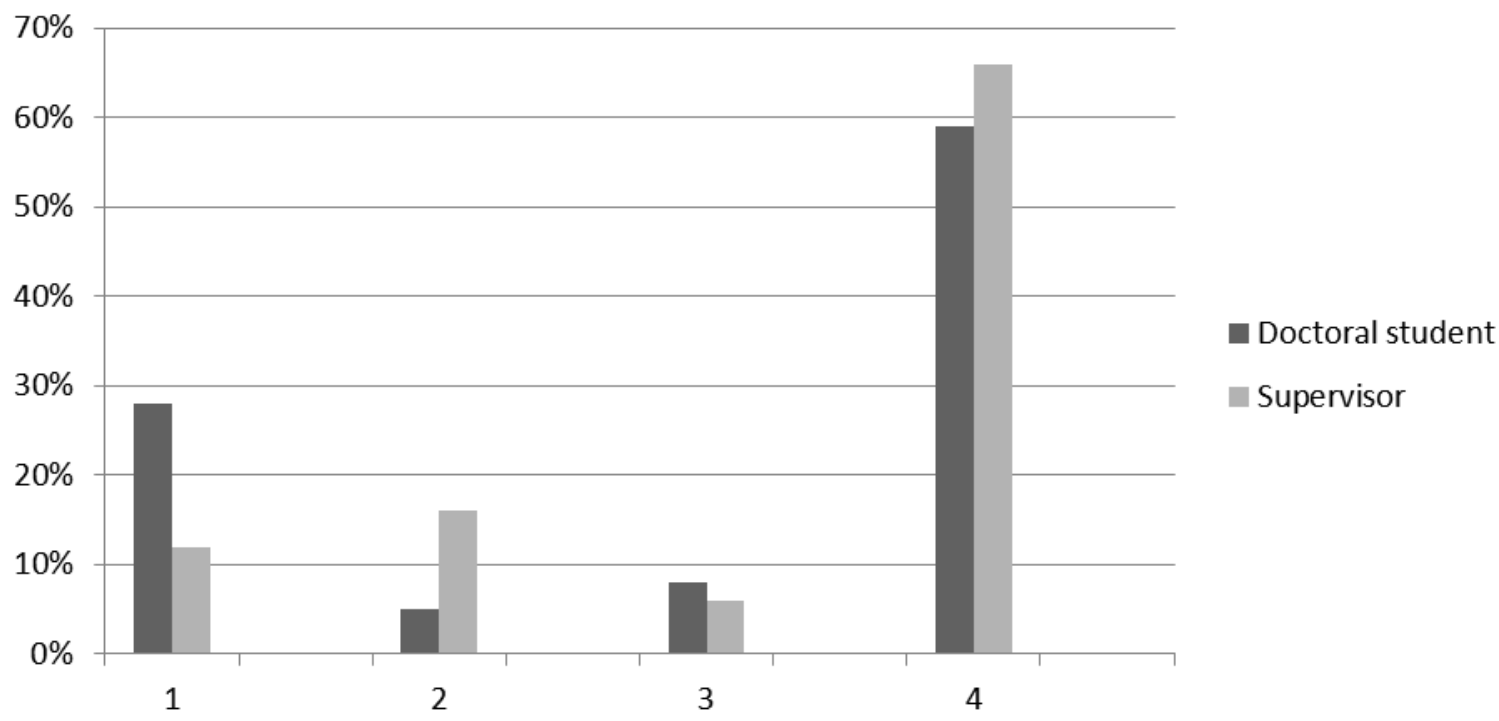

Figure 3: Challenges reported by doctoral students and supervisors $(1=$ Scholarly community and supervision, $2=$ Personal regulators, $3=$ Research-specific factors, $4=$ Structures and settings).

On the other hand, a lack of scholarly community and supervision were perceived as the central challenge by the students (Figure 3). The students described experiences of being alone, a destructive atmosphere including competition and conflicts as well as inadequate supervision, and challenges in the supervision relationship such as a lack of engagement and support. Some supervisors also described difficulties in interacting with other researchers as well as a lack of support 
and providing continuous high-quality supervision as challenging. In terms of a lack of scholarly community and supervision both the doctoral students and supervisors emphasized a lack of, or inadequate supervision as the main challenge.

The main prerequisites for doctoral training emphasized by the supervisors were structures and resources (39\%). The supervisors described the significance of financial security, clear and longterm financing, and organization of the doctoral training such as student recruitment, access to proper research facilities, and sufficient time to pursue a $\mathrm{PhD}$. In addition to continuous finance, the students pointed out a supportive personal life and professional work-life outside academia, full-time studies and holding a post in the university, work peace, as well as flexible and supportive doctoral study courses as optimal resources. Both the doctoral students and supervisors identified financial security as the main resource.

Funding: One gets doctoral student status with academic merits and that is not connected to funding. This is good because this way the path to doctoral studies is open for everybody. Of course it slows down the pace of studies when students have to earn their living by working somewhere else at the same time. I don't think this is a problem however. (Supervisor)

Secured funding for four years at the beginning and the opportunity to get funding for finishing the project. This guarantees the peace to concentrate on the project. (Supervisor)

The opportunity in your work also to do your doctoral thesis. (Doctoral student)

Funding - for both working and travelling expenses. I see doctoral projects as equivalent to other jobs so one should get paid to do it. If my funding ends, so do my doctoral studies. (Doctoral student)

The students (25\%) and supervisors (29\%) also stressed personal regulators as an important resource in the doctoral process. These included descriptions of students' motivation, selfregulation, efficacy, and engagement. Along with these, the students also reported the importance of their own active efforts and persistence. However, the supervisors $(16 \%)$ highlighted student characteristics such as a lack of motivation and self-regulative skills as key impediments more often than the students $(5 \%)$.

My own interest towards research work and knowledge building. The development of my own field in the last two decades has endorsed my personal interest. (Doctoral student)

One's own motivation is essential. It was important that I was able to plan myself what I would study and that the results matter outside academia. (Doctoral student)

Talent and applicability. The entrance requirements could be tighter: higher quality and a smaller number of doctoral students who would have more time and money to do their work. It is in nobody's interest that every "dummy" decides to do a PhD. (Supervisor)

A doctoral student's own motivation and researcher personality. The ability to find information and apply it with creativity. Professional skills, for example statistical knowledge and associated skills. (Supervisor)

Furthermore, a minority of students (4\%) and supervisors (9\%) emphasized research-specific factors as an important resource in the doctoral process. The students and supervisors typically described good research projects, plans and settings, a clearly defined research subject and questions, as well as methodological know-how as important. On the other hand, the supervisors perceived difficulties with the research project, research plan, and defining the subject as being an 
impediment. Further, the students also perceived problems with academic writing and with certain aspects of research such as data collection and analysis as well as publishing as important hindering factors.

A student's own topic that combines the development of some method and publishing the results. (Doctoral student)

Seeing the results and getting one's own articles accepted. (Doctoral student)

The formation of a research question and the theoretical background as thoroughly as possible so that the work progresses instead of just expanding. (Supervisor)

A good (specified, clear and realistic) research plan with smaller goals along the way and a good schedule. (Supervisor)

Further investigation showed that both the students (59\%) and supervisors (66\%) most often perceived a lack of resources and structures as the main challenges that hindered the doctoral process (Figure 3). However, within this category the doctoral students more often emphasized a lack of other resources and structures while the supervisors more often emphasized a lack of funding as the main challenge. The supervisors described financial insecurity and continuously applying for financial assistance as the main impediments. The students, on the other hand, typically described problems in combining and balancing doctoral studies, personal lives, and other professional duties as well as challenges in their PhD education such as the lack of relevant courses and excessive bureaucracy as the main hindering factors.

If one is not able to work as planned due to lack of funding (there are other jobs that take time off from research work). (Supervisor)

Problems in funding. One cannot do a thesis without funding. If one does not have funding for four years in a row, a lot of time and energy goes into applying for funding. This way the research does not progress. (Supervisor)

The administrative load, in the form of graduate courses, extensive teaching appointments and several committee meetings. (Doctoral student)

Funding is hard to get and the monthly amounts are small. This increases financial insecurity and stress and forces students to find sources of funding elsewhere. This lowers the efficiency. All doctoral students should be paid staff at the university and other sort of funding should be used as extra. Doctoral students are in very unequal positions and those who have funding from outside university have to pay for the use of different kinds of resources, for example rooms at the university even if they are doing their work for the university. The money that comes from doctoral theses should be directed to doctoral students' work. (Doctoral student)

To deepen the answer to research question 2 ("Were there differences between the students' and supervisors' perceptions of the primary challenges and resources?"), we found that both the emphasis on the resources $\left(\chi^{2}=76.611, \mathrm{df}=3, \mathrm{p}=.000\right)$ and the challenges $\left(\chi^{2}=53.996, \mathrm{df}=3, \mathrm{p}=\right.$ $.000)$ vis-à-vis the doctoral process differed between the students and the supervisors. Further investigation also revealed a variation in how students and supervisors of different faculties perceived resources and challenges.

In the students' answers to research question 3, where we asked about challenges and resources the students reported related to their satisfaction with the overall study process, supervision and consideration of withdrawing from the doctoral studies, we found that altogether $37 \%$ of all students had considered interrupting their doctoral studies. The results suggested that students' perceptions of hindering factors to the doctoral process were related to their intentions to interrupt 
their studies $\left(\chi^{2}=16.972, \mathrm{df}=3, \mathrm{p}=.001\right)$. Students who considered aspects related to supervision and the scholarly community hindering the process the most were most likely to have considered interrupting their doctoral studies. Furthermore, perceptions of both hindering and prompting factors were related to how satisfied students were with supervision and doctoral training in general. Students who emphasized supervision and the scholarly community as important promoting factors were also most satisfied with their supervision $\left(\chi^{2}=51.760, \mathrm{df}=6, \mathrm{p}=.000\right)$. They were also most satisfied with doctoral training in general along with those who considered research specific factors as important promoting factors $(\mathrm{F}=8.067, \mathrm{df}=3, \mathrm{p}=.000)$.

\section{Fit between Students' and Supervisors' Perceptions of Resources and Challenges vis-à-vis the Doctoral Process in Different Faculties}

To answer research question 4, concerning whether faculties differ from each other in terms of the fit between the students' and supervisors' perceptions of the primary challenges and resources, we formed three categories to illustrate the fit between the doctoral students' and supervisors' perceptions of primary resources and challenges vis-à-vis the doctoral process in different faculties. Overall, differences between the faculties in terms of whether the students and supervisors identified similar or different resources and challenges were found.

In the Faculties of Pharmacy, Behavioural Sciences, Science, and Law the students and supervisors perceived the main resources and challenges similarly. This conclusion was based on $\chi^{2}$-tests that indicated no differences between students' and supervisors' perceptions of the resources or challenges. In these faculties both students and supervisors had adopted a shared understanding of the significance of the scholarly community and supervision, as well as of personal regulators, research-specific factors and structures and resources as core assets and impediments in the doctoral process. In other words, there was a fit between the students' and the supervisors' perceptions of the resources and challenges involved in pursuing a $\mathrm{PhD}$.

Moreover, in the Faculties of Veterinary Medicine, Arts, Agriculture and Forestry, and Theology the students and supervisors perceived the core resources and challenges partly in a similar manner. This conclusion was based on $\chi^{2}$-tests that indicated differences in how students' and supervisors' perceived either resources or challenges. They typically had similar perceptions of the core impediments in the doctoral process. For instance, they both identified a lack of supervision and a scholarly community, problems with personal regulators, and research-specific factors as well as with structures and resources, as core challenges in the doctoral process. However, they understood the resources differently. Within these faculties, the students more often emphasized the scholarly community and supervision, whereas the supervisors underlined structures and resources as the core resources of the dissertation process. Therefore, a partial fit existed between the students' and the supervisors' understanding of the assets and impediments involved in pursuing a doctoral degree.

However, in the Faculties of Biological and Environmental Sciences, Medicine, and Social Sciences the students and supervisors perceived the main resources and challenges differently. This conclusion was based on $\chi^{2}$-tests that indicated differences between students' and supervisors' perceptions of both resources and challenges. They had diverging understandings of the importance of the scholarly community and supervision, personal regulators, research-specific factors and structures and resources as assets and challenges in the doctoral process. For the core resources the students typically emphasized the scholarly community and supervision, whereas the supervisors perceived structures and resources as the most important assets. Instead, the supervisors emphasized a lack of structures and resources as well as personal regulators as the primary impediments. The students, on the other hand, not only perceived a lack of structures and 
resources but also of a scholarly community and supervision as the significant challenge. In other words, a misfit was found between the students' and supervisors' perceptions of the resources and challenges involved in pursuing a $\mathrm{PhD}$.

\section{Student's Satisfaction with Doctoral Education and Supervisory Support in Different Faculties}

In their answers to research question 5, i.e., whether the fit between perceived challenges and resources was related to the students' satisfaction with their overall study process and supervision, we found that overall the doctoral students were rather satisfied with their doctoral education $($ mean $=3.4, \mathrm{sd}=0.9)$. However, Table 2 shows that the students in faculties where either a fit or partial fit existed between theirs and their supervisors' perceptions of resources and challenges reported themselves to be more satisfied with the overall doctoral education than the students from misfit faculties, where the students and the supervisors had differing perceptions.

On average, the students also reported being rather satisfied with their supervisory support $($ mean $=3.5, \mathrm{sd}=1.0)$. However, Table 2 shows that students from faculties where a fit or partial fit existed between their and the supervisors' understanding experienced more satisfaction with supervisory support than the students from misfit faculties. The differences were statistically significant.

Table 2: Differences in satisfaction with doctoral education and supervision between students from different faculties measured by ANOVA

\begin{tabular}{|l|l|l|l|l|}
\hline $\begin{array}{l}\text { THE SCALE } \\
\mathbf{1 - 5}\end{array}$ & $\begin{array}{l}\text { FIT } \\
\text { M(SD) }\end{array}$ & $\begin{array}{l}\text { PARTIAL FIT } \\
\text { M(SD) }\end{array}$ & $\begin{array}{l}\text { MISFIT } \\
\text { M(SD) }\end{array}$ & SIGNIFICANCE \\
\hline $\begin{array}{l}\text { Satisfaction with } \\
\text { doctoral education }\end{array}$ & $3.5(0.9)$ & $3.4(1.0)$ & $3.3(1.0)$ & $\mathrm{F}=3.975, \mathrm{df}=2, \mathrm{p}=.019$ \\
\hline $\begin{array}{l}\text { Satisfaction with } \\
\text { supervisory support }\end{array}$ & $3.6(0.9)$ & $3.6(1.0)$ & $3.4(1.0)$ & $\mathrm{F}=4.533, \mathrm{df}=2, \mathrm{p}=.011$ \\
\hline
\end{tabular}

\section{Conclusions}

In the present study, a mixed-method approach along with an abductive strategy using openended questions was chosen to explore the fit between doctoral students' and supervisors' perceptions of resources and challenges with respect to the doctoral process. To our knowledge, no previous studies have been conducted on doctoral student engagement that considers the fit between the supervisors' and students' perceptions of the core resources and challenges vis-à-vis the doctoral process. Hence, this study provides new insights into the fit in terms of similarities and differences in supervisors' and students' perceptions of resources and challenges in the doctoral process as well as the differences between various faculties. The study also contributes to understanding the ways in which the fit is related to students' satisfaction with the process and their supervision.

Our findings suggest that both the students' and supervisors' descriptions of the main resources and challenges in the doctoral process were related to the scholarly community and supervision, structures and resources, personal regulators, and research-specific factors. However, in regard to some of the resources and challenges the supervisors and students had different emphases. For instance, the supervisors pointed out a good financial situation and a lack of funding as the main resources and challenges, respectively. In turn, the students' emphasis was on more on personal life and professional work-life. A reason for this may be that it is the responsibility of the supervi- 
sors to apply and secure funding for their students, and, hence, they may be more aware of the criticality of the financial situations associated with doctoral studies. Moreover, the students' perceptions of both resources and challenges were related to their intentions to interrupt their studies, satisfaction with supervision as well as satisfaction with doctoral training in general. Hence, perceived resources and challenges are related to student satisfaction and persistence. These findings imply that the job-demand resource model (Bakker \& Demerouti, 2007; Demerouti et al., 2001; Pyhältö, Pietarinen, \& Salmela-Aro, 2011) provided a functional grounding for exploring factors contributing to doctoral studies. Moreover, the results indicate that both resources and challenges may originate from various sources. Accordingly, the findings supported the previous research into doctoral education, which suggests that doctoral education is a complex nested entity (Leech 2012; MacAlpine \& Norton, 2006; Pyhältö et al., 2009).

Further, variation was also observed between the faculties: a fit, partial fit, or misfit was identified between the supervisors' and doctoral students' perceptions of the primary resources and challenges vis-à-vis the doctoral process. Hence, similar perceptions about the primary resources and demands between supervisors and students cannot be taken for granted. The results indicate that the variation between faculties cannot be explained by disciplinary differences. Such differences have been pointed out between the hard and soft sciences (Becher, 1989). For instance, a misfit, partial fit, and fit between students' and supervisors' perceptions of the resources and challenges existed both in faculties representing so-called hard sciences (e.g., Pharmacy, Veterinary Medicine, and Biological and Environmental Sciences) and soft sciences (e.g., Behavioural Sciences, Arts, and Social Sciences). A reason for this may be that the working environment, for instance, supervision practices and interaction of each faculty contributes to the similarities and differences between the students' and supervisors' understanding rather than disciplinary differences.

The results suggest that the perceived fit is linked to the doctoral students' experienced satisfaction with their studies and the supervisory relationship: The students in faculties that fitted or partially fitted reported themselves to be more satisfied with their overall study process and supervisory support. The findings indicate that the fit between students and their working environment is related to the students' satisfaction with both their doctoral studies and supervision. Accordingly, discrepancies between the students' and supervisors' perceptions are likely to reduce student satisfaction. This result is consistent with previous studies of undergraduate and graduate students, which suggests that the perceived fit contributes to study engagement (Gilbreath, Kim, \& Nichols, 2011; Schmitt, Oswald, Friede, Imus, \& Merritt, 2008). For instance, Gilbreath et al. (2011) found that the fit between undergraduate students and their university environment was related to satisfaction with their university as well as psychological wellbeing.

The findings also suggest that the fit between supervisors and students is a determinant of student engagement in pursuing a PhD. Our results implied that a shared understanding of the resources and challenges between the doctoral students and supervisors is related to students' satisfaction. In terms of developing doctoral education as a more engaging working environment for doctoral students this indicates that arenas for shared meaning-making between doctoral students and their environments are needed. A better fit can be constructed by facilitating shared meaning-making among doctoral students and supervisors regarding resources and challenges in the doctoral process. In practice, this can be supported, for instance, by encouraging supervisors and students to reveal and elaborate on their perceptions in supervisory discussions. Such elaborations may support supervisors and students to construct a shared understanding of the focus of supervision. For instance, in a problematic situation this may help both students and supervisors to identify what the challenges are and how to deal and cope with them. Supervisory discussions on the resources and challenges are important especially at the beginning of the doctoral process when supervisory relationships are formed and students plan and launch their doctoral projects. Golde (1998), for 
instance, showed that one of the main reasons for doctoral students leaving their studies during the first year was a mismatch between the students and their supervisors including dissimilar working styles. This indicates that there may be a need for orientation periods at the beginning of the studies for doctoral students and supervisors in order to find the best possible shared understanding in the supervisory relationship. This may be one of the ways to promote a better fit between the student and their working environment, and hence foster student satisfaction and persistence in their doctoral studies.

In the present study, we were able to provide insight into the fit between doctoral students and their working environments and how they are linked to students' satisfaction at a certain point of time. We acknowledge that person-environment fit is not a static process but rather one that unfolds over time. To improve our understanding of the doctoral student-environment fit as a dynamic process in further research it would be important to attempt to consider the fit between doctoral students and their working environment using a longitudinal approach as well as more in-depth qualitative methods.

\section{References}

Appel, M., \& Dahlgren, L. (2003). Swedish doctoral students' experiences on their journey towards a PhD: Obstacles and opportunities inside and outside the academic building. Scandinavian Journal of Educational Research, 47(1), 89-110.

Appleton, J. J., Christenson, S. L., Kim, D., \& Reschly, A. L. (2006). Measuring cognitive and psychological engagement: Validation of the Student Engagement Instrument. Journal of School Psychology, 44, 427-445.

Bakker, A., \& Demerouti, E. (2007). The job demands-resources model: State of the art. Journal of Managerial Psychology, 22, 309-328.

Barnes, B. J., \& Austin, A. E. (2009). The role of doctoral advisors: A look at advising from the advisor's perspective. Innovative Higher Education, 33(5), 297-315.

Becher, T. (1989). Academic tribes and territories: Intellectual enquiry and the culture of disciplines. Stony Stratford, UK: Society for research in higher education/ Open University Press.

Bozeman, B., Dietz, J. S., \& Gaughan, M. (2001). Scientific and technical human capital: An alternative model for research evaluation. International Journal of Technology Management, 22(7-8), 716-740.

Brailsford, I. (2010). Motives and aspirations for doctoral study: Career, personal, and inter-personal factors in the decision to embark on history PhD. International Journal of Doctoral Studies, 5, 15-27. Retrieved from http://ijds.org/Volume5/IJDSv5p015-027Brailsford283.pdf

Bryman, A. (2004). Social research methods (2nd ed.). Oxford, UK: Oxford University Press.

Case, J. (2008). Alienation and engagement: Development of an alternative theoretical framework for understanding student learning. Higher Education, 55(3), 321-332.

Coffey, A., \& Atkinson, P. (1996). Making sense of qualitative data. Complementary research strategies. Thousand Oaks, CA: Sage.

Cook, C., Heath, F., \& Thompson, R. (2000). A meta-analysis of response rates in Web- or Internet-based surveys. Educational and Psychological Measurement, 60(6), 821-836.

Cook, M. M, \& Swanson, A. (1978). The interaction of student and program variables for the purpose of developing a model for predicting graduation from graduate programs over 10-year period. Research in Higher Education, 8(1), 83-91.

Creswell, J. W. (2003). Research design. Qualitative, quantitative and mixed methods approaches (2nd ed.). Thousand Oaks: Sage. 
Demerouti, E., Bakker, A. B., Nachreiner, F., \& Schaufeli, W. B. (2001). The job demands - Resources model of burnout. Journal of Applied Psychology, 86, 499-512.

Dill, D.D., Mitra, S. K., Jensen, S., H., Lehtinen, E., Mäkelä, T., Parpala, A., .. Saari, S. (2006). PhD training and the knowledge-based society: An evaluation of doctoral education in Finland. Publications of Finnish Higher Education Evaluation Council. Tampere: Tampere-Paino Oy.

Dysthe, O., Samara, A., \& Westrheim, K. (2006). Multivoiced supervision of Master's students: A case study of alternative supervision practices in higher education. Studies in Higher Education, 31(3), 299318 .

Edwards, J. R. (2007). The relationship between person-environment fit and outcomes: An integrative theoretical framework. In C. Ostroff \& T. A. Judge (Eds.), Perspectives on organizational fit (pp. 209258). San Francisco: Jossey-Bass.

Edwards, J. R., Cable, D. M., Williamson, I. O., Schurer Lambert, L., \& Shipp, A. J. (2006). The phenomenology of fit: Linking the person and environment to the subjective experience on person environment fit. Journal of Applied Psychology, 91(4), 802-827.

Eggleston, J., \& Delamont, S. (1983). Supervision of students for research degrees. Birmingham, AL: BERA.

Ehrenberg, R. G., Jakubson, G. H., Groen, J. A., So, E., \& Price, J. (2007 ). Inside the black box of doctoral education: What program characteristics influence doctoral students' attrition and graduation probabilities? Educational Evaluation and Policy Analysis, 29(2), 134-150.

Finland's Council of State. (2004). Regulation of university degrees 645/1997 [In Finnish]. Retrieved 7 February, 2012 from http://www.finlex.fi/fi/laki/alkup/2004/20040794

Franke, A., \& Arvidsson, B. (2011). Research supervisors' different ways of experiencing supervision of doctoral students. Studies in Higher Education, 36(1), 7-19.

Gardner, S. K. (2007). "I heard it through the grapevine": Doctoral student socialization in chemistry and history. Higher Education, 54(5), 723-740.

Gardner, S. K. (2008). Fitting the mold of graduate school: A qualitative study of socialization in doctoral education. Innovations in Higher Education, 33, 125-138.

Gardner, S. K. (2009). Student and faculty attributions of attrition in high and low-completing doctoral programs in the United States. Higher Education, 58, 97-112.

Gardner, S. K. (2010). Doctoral student development. In S. K. Gardner \& P. Mendoza (Eds.), On becoming a scholar. Socialization and development in doctoral education (pp. 203-223). Virginia, USA: Stylus Publishing.

Gilbreath, B., Kim, T.-Y., \& Nichols, B. (2011). Person-environment fit and its effects on university students: A response surface methodology study. Research in Higher Education, 52, 47-62.

Golde, C. M. (1998). Beginning graduate school: Explaining first-year doctoral attrition. In M. S. Anderson (Ed.), The experience of being in graduate school: An exploration (pp. 55-64). San Francisco: JosseyBass.

Golde, C. M. (2005). The role of the department and discipline in doctoral student attrition: Lessons from four departments. The Journal of Higher Education, 76(6), 669-700.

Halse, C., \& Malfroy, J. (2010). Retheorizing doctoral supervision as professional work. Studies in Higher Education, 35(1), 79-92.

Haworth, J. G., \& Bair, C. R. (2000). Learning experiences that make a difference: Findings from a national study of doctoral education in the professions. Paper presented at a meeting of the Association for the Study of Higher Education, Sacramento: CA.

Holland, J. (1985). Making vocational choices: A theory of vocational personalities and work environments (2nd ed.). Englewood Cliffs, NJ: Prentice-Hall. 
Hopwood, N. (2010). Doctoral experience and learning from a sociocultural perspective. Studies in Higher Education, 35(7), 829-843.

Hoskins, C. M. \& Goldberg, A. D. (2005). Doctoral student persistence in counselor education programs: Student-program match. Counselor Education and Supervision, 44, 175-188.

Ives, G., \& Rowley, G. (2005). Supervisor selection or allocation and continuity of supervision: Ph.D. students' progress and outcomes. Studies in Higher Education, 30(5), 535-555.

Knowles, S. (1999). Feedback on writing in postgraduate supervision: Echoes in response-context, continuity and resonance. Supervision of Postgraduate Research in Education, 113-128.

Kristof, A. L. (1996). Person-organization fit: An integrative review of its conceptualizations, measurement, and implications. Personnel Psychology, 49(1), 1-49.

Krosnick, J. (1999). Survey research. Annual Review of Psychology, 50, 537-567.

Leech, N. L. (2012). Educating knowledgeable and skilled researchers in doctoral programs in schools of education: A new model. International Journal of Doctoral Studies, 7, 19-37. Retrieved from http://ijds.org/Volume7/IJDSv7p019-037Leech325.pdf

Levine, A. (2007). Educating researchers. Washington, DC: The Education Schools Project.

Levin-Rozalis, M. (2004). Searching for the unknowable: A process of detection - abductive research generated by projective techniques. International Journal of Qualitative Methods, 3(2), 1-18.

Lovitts, B. E. (2001). Leaving the ivory tower: The causes and consequences of departure from doctoral study. Lanham, MD: Rowman and Littlefield.

Lovitts, B. E. (2005). Being a good course-taker is not enough: A theoretical perspective on the transition to independent research. Studies in Higher Education, 30(2), 137-154.

McAlpine, L., \& Norton, J. (2006). Reframing our approach to doctoral programs: an integrative framework for action and research. Higher Education Research \& Development, 25(1), 3-17.

Mainhard, T., van der Rijst, R., van Tartwijk, J., \& Wubbels, T. (2009). A model for the supervisordoctoral student relationship. Higher Education, 58, 359-373.

Martinsuo, M., \& Turkulainen, V. (2011). Personal commitment, support and progress in doctoral studies. Studies in Higher Education, 36(1), 103-120.

Meyer, J. H. F., Shanahan, M. P., \& Laugksch, R. C. (2005). Students' conceptions of research. I: A qualitative and quantitative analysis. Scandinavian Journal of Educational Research, 49(3), 225-244.

Miles, M. B., \& Huberman, A. M. (1994). Qualitative data analysis: An expanded sourcebook (2nd ed.). Thousand Oaks, CA: Sage.

Murphy, N. W. (2004). Orientations to research higher degree supervision: The interrelatedness of beliefs about supervision, research, teaching and learning. (Doctoral dissertation, Griffith University, Brisbane, Australia.) Retrieved from https://www120.secure.griffith.edu.au/rch/file/526ad690-919a-3dc1e20f-e617b39ac839/1/02Whole.pdf

Nettles, M. T., \& Millet. C. M. (2006). Three magic letters: Getting to Ph.D. Baltimore: The John Hopkins University Press.

Morgan, D. L. (2007). Paradigms lost and pragmatism regained: Methodological implications of combining qualitative and quantitative methods. Journal of Mixed Methods Research, 1(1), 48-76.

Nutov, L., \& Hazzan, O. (2011). Feeling the doctorate: Is doctoral research that studies the emotional labour of doctoral students possible? International Journal of Doctoral Studies, 6, 19-31. Retrieved from http://ijds.org/Volume6/IJDSv6p019-032Nutov307.pdf

Patton, M. Q. (1990). Qualitative evaluation and research methods. Newbury Park, CA: Sage.

Park, C. (2007). Redefining the doctorate. Discussion paper published by The Higher Education Academy, York. 
Pearson, M., \& Brew, A. (2002). Research training and supervision development. Studies in Higher Education, 27(2), 135-150.

Protivnak, J. J., \& Foss, L. L. (2009). An exploration of themes that influence the counselor education doctoral student experience. Counselor Education \& Supervision, 48, 239-256.

Pyhältö, K., Nummenmaa, A. R, Soini, T., Stubb, J., \& Lonka, K. (2012). Research on scholarly communities and development of scholarly identity in Finnish doctoral education. In S. Ahola \& D. M. Hoffman (Eds.), Higher education research in Finland. Emerging structures and contemporary issues (pp. 337357). Jyväskylä: Jyväskylä University Press.

Pyhältö, K., Pietarinen, J., \& Salmela-Aro, K. (2011). Teacher-working-environment fit as a framework for burnout experienced by Finnish teachers. Teaching and Teacher Education, 27, 1101-1110.

Pyhältö, K., Stubb, J., \& Lonka, K. (2009). Developing scholarly communities as learning environments for doctoral students. International Journal for Academic Development, 14(3), 221-232.

Pyhältö, K., Stubb, J., \& Tuomainen, J. (2011). International evaluation of research and doctoral education at the University of Helsinki - To the top and out to society. Summary report on doctoral students' and principal investigators' doctoral training experiences. Retrieved February 20, 2012 from http://wiki.helsinki.fi/display/evaluation2011/Survey+on+doctoral+training

Pyhältö, K., Toom, A. Stubb, J., \& Lonka, K. (2012) Challenges of becoming a scholar: A study of experienced problems and well-being of doctoral students. ISRN Education. http://www.isrn.com/journals/education/aip/934941/

Reeve, J., Jang, H., Carrell, D., Jeon, S., \& Barch, J. (2004). Enhancing students' engagement by increasing teachers' autonomy support. Motivation and Emotion, 28(2), 147-169.

Sainio, J. (2010). Asiantuntijana työmarkkinoille - Vuosina 2006 ja 2007 tohtorin tutkinnon suorittaneiden työllistyminen ja heidän mielipiteitään tohtorikoulutuksesta [Experts for the labour market - The employment of doctors who earned their doctoral degree in 2006-2007 and their perceptions of doctoral training ]. Tampere. Kirjapaino Hermes Oy.

Sambrook, S., Stewart, J., \& Roberts, C. (2008). Doctoral supervision . . . a view from above, below and the middle! Journal of Further and Higher Education, 32(1), 71-84.

Scaffidi, A. K., \& Bergnman, J. E. (2011). A positive postdoctoral experience is related to quality supervision and career mentoring, collaboration, networking and a nurturing research environment. Higher Education, 62(6), 685-698.

Schmitt, N., Oswald, F. L., Friede, A., Imus, A., \& Merritt, S. (2008). Perceived fit with an academic environment: Attitudinal and behavioral outcomes. Journal of Vocational Behavior, 72, 317-335.

Seagram, B. C., Gould, J. \& Pyke, S. W. (1998). An investigation of gender and other variables on time to completion of doctoral degrees. Research in Higher Education, 39(3), 319-335.

Stubb, J., Pyhältö, K., \& Lonka, K. (2011). Balancing between inspiration and exhaustion: PhD students' experienced socio-psychological well-being. Studies in Continuing Education, 33(1), 33-50.

Styles, I., \& Radloff, A. (2001). The synergistic thesis: Student and supervisor perspectives. Journal of Further \& Higher Education, 25(1), 97-106.

Sweitzer, V. (2009). Towards a theory of doctoral student professional identity development: A developmental networks approach. The Journal of Higher Education, 80(1), 1-33.

Tuomainen, J., Pyhältö, K., \& Lonka, K. (2012). Balancing between engagement and disengagement during a PhD process. Paper presented at EARLI SIG 4 Higher Education Conference entitled: "Creativity and Innovation in Higher Education", 14-17 August 2012 in Tallinn University, Estonia.

University of Helsinki Annual Report. (2010). Retrieved February 7, 2012 from http://www.helsinki.fi/viestinta-ja-yhteiskuntasuhteet/vuosikertomus2010 en.html 
Virtanen, V., \& Pyhältö, K. (in press). What engages doctoral candidates in biological and environmental science to doctoral studies? Psychology.

Weidman, J. C., \& Stein, E. L. (2003). Socialization of graduate students to academic norms. Research in Higher Education, 44, 641-656.

Wulff, D. H., \& Nerad, M. (2006). Using an alignment as a framework in the assessment of doctoral programs. In P.L. Maki \& N.A. Borkowski (Eds.), The assessment of doctoral education. Emerging criteria and new models for improving outcomes (pp. 83-108). Sterling, Virginia: Stylus Publishing.

Yerkes, M., van de Schoot, R., \& Sonneveld, H. (2012). Who are the job seekers? Explaining unemployment among doctoral recipients. International Journal of Doctoral Studies, 7, 153-166.

Yin, R.K. (1994). Case study research: Design and methods (2nd ed.). Thousand Oaks, CA: Sage.

Zhao, C.-M., Golde, C. M., \& McCormick, A. C. (2007). More than a signature: How advisor choice and advisor behavior affect doctoral student satisfaction. Journal of Further and Higher Education, 31(3), 263-281.

\section{Biographies}

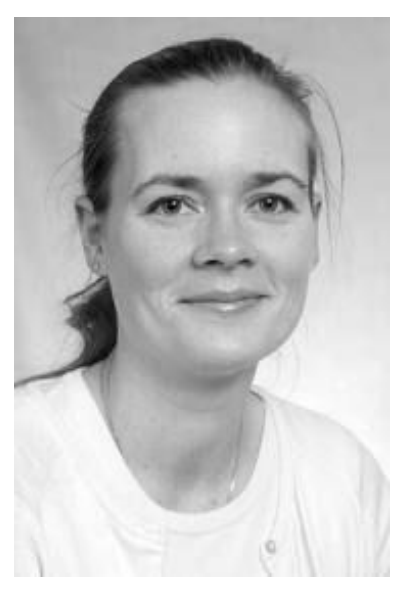

Kirsi Pyhältö, $\mathrm{PhD}$, is an adjunct professor and senior pedagogical university lecturer in higher education at the Centre for Research and Development in Higher Education, University of Helsinki, Finland. Her research interests include postgraduate education; learning and professional development in higher education and agency and wellbeing in basic education. She can be reached at kirsi.pyhalto@helsinki.fi.

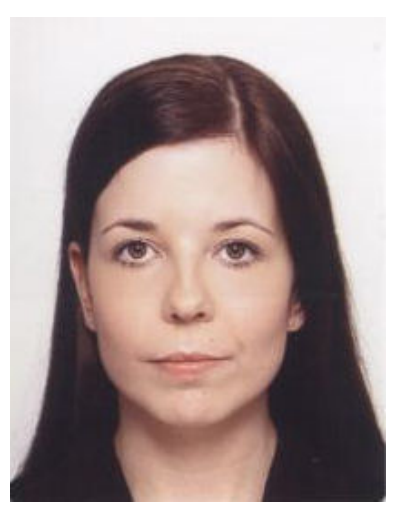

Jenna Vekkaila, M.A. (Educ.), is a PhD student in the Research Unit for Teaching and Learning Sciences in the Department of Teacher Education in University of Helsinki, Finland. Her thesis is on engagement in doctoral process and the dynamic interplay between the doctoral students and their learning/working environments. She can be reached at jenna.vekkaila@helsinki.fi. 


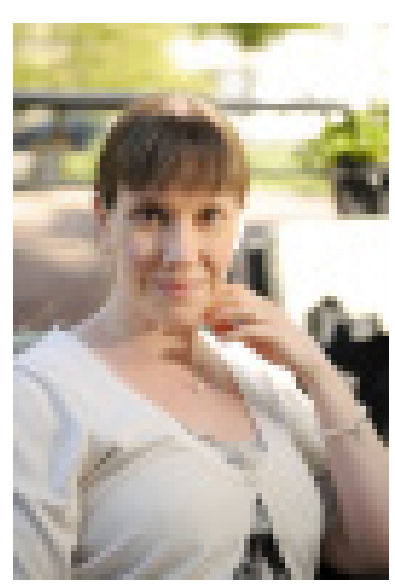

Jenni Keskinen, $\mathrm{PhD}$, is a post doc researcher in the Research Unit for Teaching and Learning Sciences in the Department of Teacher Education in University of Helsinki, Finland. Her research interests include postgraduate education; experienced well-being and engagement in the $\mathrm{PhD}$ process. She can be reached at jenni.keskinen@helsinki.fi. 